\title{
BK Virus-Associated Nephropathy after Renal Transplantation
}

\author{
Yasuhito Funahashi
}

check for updates

Citation: Funahashi, Y. BK Virus-Associated Nephropathy after Renal Transplantation. Pathogens 2021, 10, 150. https://doi.org/ $10.3390 /$ pathogens 10020150

Academic Editor: Yoshiko Matsuda Received: 7 January 2021

Accepted: 29 January 2021

Published: 2 February 2021

Publisher's Note: MDPI stays neutral with regard to jurisdictional claims in published maps and institutional affiliations.

Copyright: (C) 2021 by the author. Licensee MDPI, Basel, Switzerland. This article is an open access article distributed under the terms and conditions of the Creative Commons Attribution (CC BY) license (https:/ / creativecommons.org/licenses/by/ $4.0 /)$.
Departments of Urology, Nagoya University Graduate School of Medicine, Aichi 466-8550, Japan; yfunahashi@med.nagoya-u.ac.jp; Tel.: +81-52-744-2985; Fax: +81-52-744-2319

\begin{abstract}
Recent advances in immunosuppressive therapy have reduced the incidence of acute rejection and improved renal transplantation outcomes. Meanwhile, nephropathy caused by BK virus has become an important cause of acute or chronic graft dysfunction. The usual progression of infection begins with BK viruria and progresses to BK viremia, leading to BK virus associated nephropathy. To detect early signs of BK virus proliferation before the development of nephropathy, several screening tests are used including urinary cytology and urinary and plasma PCR. A definitive diagnosis of BK virus associated nephropathy can be achieved only histologically, typically by detecting tubulointerstitial inflammation associated with basophilic intranuclear inclusions in tubular and/or Bowman's epithelial cells, in addition to immunostaining with anti-Simian virus 40 large T-antigen. Several pathological classifications have been proposed to categorize the severity of the disease to allow treatment strategies to be determined and treatment success to be predicted. Since no specific drugs that directly suppress the proliferation of BKV are available, the main therapeutic approach is the reduction of immunosuppressive drugs. The diagnosis of subsequent acute rejection, the definition of remission, the protocol of resuming immunosuppression, and long-term follow-up remain controversial.
\end{abstract}

Keywords: BK virus; BK virus-associated nephropathy; renal transplantation

\section{Introduction}

The survival of transplanted kidney grafts has improved with the development of novel immunosuppressive therapies. However, among the several types of polyomavirus infectious in humans, since Purighalla et al. first reported in 1995 [1], BK virus (BKV) has been increasingly recognized as the major pathogenic virus after renal transplantation, and it can lead to BKV associated nephropathy (BKVAN). The double-stranded DNA genome of BKV consists of three functional regions: the early viral gene region encoding the regulatory large $\mathrm{T}$ - and small $\mathrm{t}$-antigen; the late viral gene region encoding the viral capsid proteins $\mathrm{Vp} 1, \mathrm{Vp} 2, \mathrm{Vp} 3$, the non-structural agnoprotein, and a pre-microRNA giving rise to miRNA-5p and $-3 p$; and the non-coding control region containing the origin of viral genome replication ori as well as regulatory sequences [2,3]. Most individuals become seropositive by approximately four years of age and 70-90\% of adults have antibodies to $\mathrm{BKV}[4,5]$. Following primary infection via the respiratory route, BKV remains latent in the renourinary tract, B cells, brain, and spleen [6].

Under the strong immunosuppression after renal transplantation, latent polyomavirus reactivates in the kidney, causing lytic destruction of renal tubular epithelial cells, and resulting in tubular fluid accumulation in the interstitial compartment, which is characterized by an inflammatory interstitial nephropathy, associated with functional impairment due to tubular fibrosis and atrophy [7]. Recently, regular screening for BKV replication by quantitative PCR and pre-emptive reduction of immunosuppression in viremic patients have become common among kidney transplant centers, resulting in a decreased prevalence of biopsy-proven BKVAN [8]. However, a substantial proportion of kidney transplant recipients experience clinically significant BKVAN; viruria in 30-60\%, viremia in $10-30 \%$, and BKVAN in up to $10 \%$ [6,9-16]. For the treatment of BKVAN, clinicians mainly 
reduce immunosuppressive drugs, since BKV-specific anti-viral therapy is not yet available. However, a reduction in immunosuppressive drugs can lead to immunological rejection and these treatment failures can lead to transplanted kidney loss. This review summarizes the recent management of BKVAN after renal transplantation.

\section{Risk Factors}

Many clinical studies have reported risk factors for BKVAN. Representative risk factors are renal transplantation from deceased donors, episodes of acute rejection, and Tacrolimus and/or MMF-based maintenance immunosuppression [17,18]. In addition, several factors associated with donors, recipients, and others have been proposed as promoting a high risk of BKVAN development (Table 1). On the other hand, the combined immunosuppression with mTOR inhibitor is reported to promote favorable outcomes $[19,20]$.

Table 1. Reported risk factors for BKVAN.

\begin{tabular}{ll}
\hline Donor factors & Deceased donor [21] \\
& BKV viruria [22] \\
& High BKV antibody titers [23,24] \\
& Female gender [21] \\
& Degree of HLA mismatches [21,25] \\
& Positivity of HLA A9 [26], G 3'UTR-4 [27] \\
& Negativity of HLA C7 [28,29] \\
\hline Recipient factors & Older age [21] \\
& Male gender [21] \\
& ABO incompatibility [30] \\
& History of hemodialysis [31] \\
& Low BKV antibody titers [24] \\
& African American [32] \\
& Diabetes [21] \\
& Positivity of HLA A2 [26], G 3'UTR-4 [27] \\
& Negativity of HLA C7 [28], B51 [33] \\
& Acute rejection and antirejection treatment [25,34,35] \\
& Delayed graft function [36] \\
& Cold ischemia time [37] \\
& Steroid exposure [38] \\
& Tacrolimus levels [38] \\
& Tacrolimus and/or MMF-based maintenance \\
immunosuppression [21,31,39] & Ureteric stent replacement [40] \\
\hline Transplant factors &
\end{tabular}

\section{Screening}

An allograft needle biopsy is required for a definitive diagnosis of BKVAN [41], but cannot be performed easily due to its invasiveness. Several screening methods have been developed to identify viral activation and renal tissue damage before the development of BKVAN. Such screening permits early diagnosis and reduction in immunosuppressive drugs before the development of irreversible functional impairment of the transplanted kidney. Current guidelines recommend that BKV reactivation should be monitored by regular screening for cytology or viral DNA in urine or plasma [14].

\subsection{Plasma PCR}

Many studies have reported that regular screening for plasma viral load by real-time PCR is useful to identify early viral replication, permit intervention, and prevent progression to BKVAN or allograft loss $[10,13,20,42]$. Screening for BK viremia can identify at least $90 \%$ of patients at risk of BKVAN before significant functional impairment of the renal allograft occurs [43]. Although the optimal frequency and screening methodology remain unclear, the American Society of Transplantation (AST) Infectious Diseases Guidelines recommended regular plasma BKV monitoring of monthly until month 9, and then every 
three months until two years, then reducing annually until five years [14]. Frequent BKV surveillance should be considered beyond 2 years post-transplantion in pediatric patients because of their high prevalence of BKVAN [44].

Many studies have examined the relationship between urine or plasma BKV levels and diagnosis of BKVAN $[6,45,46]$. Viscount et al. reported that a plasma BKV DNA level of $>1.6 \times 4 \log _{10} \mathrm{c} / \mathrm{mL}$ and a urine BKV DNA level of $>2.5 \times 7 \log _{10} \mathrm{c} / \mathrm{mL}$ were strongly associated with BKVAN [46]. Hirsch et al. reported that a plasma BKV DNA level of $>4 \log _{10} \mathrm{c} / \mathrm{mL}$ is recommended for a presumed diagnosis of BKVAN, and the urine viral load in affected patients exceeded $7 \log _{10} \mathrm{c} / \mathrm{mL}$ [6]. The Kidney Disease: Improving Global Outcomes (KDIGO) clinical practice guidelines also suggest reduction of immunosuppression when the BKV load in plasma is persistently $>4 \log _{10} \mathrm{c} / \mathrm{mL}$, to prevent disease progression to an irreversible phase [47]. These studies concluded that a presumed diagnosis of BKVAN can be made based on surrogate markers of plasma viral replication. Current guideline mentions that significant BKV replication is assumed when plasma BKV loads of $>3 \log _{10} \mathrm{c} / \mathrm{mL}$ are found in two measurements within three weeks (probable BKVAN), or if loads increased to $>4 \log _{10} \mathrm{c} / \mathrm{mL}$ in at least one of two measurements (presumptive BKVAN) [18]. In these cases with normal baseline renal function, clinicians should start reducing immunosuppression without need for graft biopsy.

In clinical practice, a survey of screening methods among 42 medical centers in the United States reported $42 \%$ screening of blood alone, $37 \%$ of urine and blood, $17 \%$ of urine alone, and $2 \%$ of urine cytology [48]. A survey of 90 pediatric physicians in 27 European countries reported that $37 \%$ screened blood alone, $37 \%$ screened urine and blood, and $26 \%$ screened urine alone [49].

\subsection{Urine PCR}

Approximately half of those with high-level viruria develop BK viremia 2-6 weeks later, and again approximately half of the latter are diagnosed with biopsy-proven BKVAN after another 2-6 weeks [50]. Therefore, early signs of viral proliferation in the kidney can be evaluated by quantifying the BKV load in urine. Determining the viral load using PCR addresses weakness in urinary cytology; namely, the lack of specificity and sensitivity, and allows quantification of disease severity [46]. Monitoring BKV in the urine for an early diagnosis of polyomavirus reactivation is valuable for identifying patients at increased risk for BKVAN [51].

The detection rate of BKV in urine varies among studies [9-12]. Hsieh et al. investigated viral DNA in urine among 250 renal transplant recipients and reported a prevalence of 20.4\% [10]. Saundh et al. examined urine in 30 renal-transplant patients at five days and at $1,3,6$, and 12 months. They reported that $27 \%$ were positive for $B K V$, and $B K$ viruria was mainly detected at 3-6 months after renal transplantation [12]. We also reported that detection of BKV in urine was high during the first six months, and decreased gradually after renal transplantation [11].

Patients with active BKVAN showed a BKV DNA load of $>7-8 \log _{10}$ copies $/ \mathrm{mL}$ in urine samples $[6,46,52,53]$. However, BKV is latently present in urothelial cells, even in normal populations; therefore, detection of BKV DNA in urine does not always support the presence of a tubulointerstitial disorder. It is generally thought that BK viruria alone, especially in cases with a low urinary BKV load, is of little clinical significance. Screening of healthy adults reported a positive rate of asymptomatic BK viruria of 7\% [54]. BK viruria is observed in $8-16 \%$ of donors and recipients prior to transplantation [55-57]. After renal transplantion, detection of urinary BKV DNA of $<5 \log _{10}$ copies $/ \mathrm{mL}$ without any clinical problems is seen in approximately $10 \%$ [54].

Quantification of urine viral load in BKVAN screening is superior to quantification of plasma viral load in several aspects. BKV appears in urine before plasma in the development of BKVAN; negative predictive value of testing urinary BKV DNA is high with a longer period before the onset of viremia and BKVAN. Therefore, quantification of the urine viral load is more suitable to evaluate BKVAN risk at an earlier stage. However, clini- 
cians should interpret a low BKV load in urine cautiously; lower specificity and delayed or lack of viral clearance from the urine after treatment could lead to over-reduction of immunosuppression and the risk of subsequent acute rejection.

Urine PCR test is sensitive but not specific to the diagnosis of BKVAN, therefore, it may be useful for identifying patients at risk before they develop viremia or BKVAN.

\subsection{Urine Cytology}

For the detection of early sign of BKV replication in the transplanted kidney, urine cytology is useful for screening high-risk patients [58]. Virus-infected urothelial cells called "decoy cells", identified by their typical ground glass intranuclear inclusions on cellular smears stained by the Papanicolaou method, are observed in most patients with BKVAN. Most decoy cells are thought to originate from the renal tubules [59-61]. Ariyasu et al. simultaneously immunostained urine specimens with antibodies for S100P and Simian virus 40 (SV40) large T-antigen to determine the origin of decoy cells; $97 \%$ of BKV-infected cells originated in the renal tubule [61]. Decoy cell shedding as well as viruria precedes viremia or the development of BKVAN [25]. It can be observed when urine BKV increases to approximately $4-5 \log _{10} \mathrm{c} / \mathrm{mL}$ [62], when BKV is not amplified in plasma in many cases. However, decoy cells are not specific for the presence of BKV in urine and can be found in JC polyomavirus and adenovirus infection [62-65].

The correlation between decoy cell number and the severity of renal injury remains controversial. Koh et al. reported that urinary decoy cell number is associated with sustained cell shedding, positive urinary PCR results, and the development of BKVAN [66]. On the other hand, Singh et al. found no correlation between the severity of BKVAN and either decoy cell counts or BKV DNA levels in plasma or urine [67]. Nevertheless, the cytological evaluation of decoy cells in urine is useful in daily practice because of its low cost and non-invasiveness. Many clinicians initially perform urinary cytology tests and then perform PCR if decoy cells are persistently found.

\subsection{Potential Diagnostic Markers}

To overcome the limitations of urinary cytology and urine/plasma PCR for BKV DNA, a lot of biomarkers have been proposed as non-invasive tests for the diagnosis of BKVAN in renal transplant recipients. Singh et al. found that dense, cast-like polyomavirus aggregates termed 'polyomavirus-Haufen' were present in fixed voided urine samples by negatively stained electron micrographs and were correlated with the clinical course [68]. In addition, the quantification of its number was correlated with the severity of BKVAN [67]. Mass spectrometric detection of peptides derived from Vp1 has allowed BKV subtypes I and IV to be differentiated [69]. Konietzny et al. reported an association between higher decoy cell numbers and the presence of the Vp1 subtype Ib-2 [70]. In addition, heat shock protein 90- $\alpha$ [71], CXCL9 and 10 [72], Neutrophil gelatinase-associated lipocalin [73], BKV genotyping [74], BKV-specific CD4+ T-cells [75], and urinary exosomal BKV microRNA [76] have been also reported for its usefulness. None of these have been introduced for clinical application.

\section{Histology}

\subsection{Histological Findings}

For diagnosing all of the major allograft disorders, such as acute rejection, chronic allograft nephropathy, and acute tubular necrosis, renal allograft biopsy is the "gold standard". In BKVAN, a renal biopsy can provide useful information about the extent of renal scarring, type and extent of immune response, and the existence of concurrent pathologies [77].

Since BKV replicates focally in the kidneys, allograft biopsy may sometimes miss the characteristic histological findings of BKVAN, especially when needle biopsies are taken during the early phase of disease or there is a lack of medullary tissue [78]. In BK viremia-positive patients who have multiple biopsy cores collected at the same time, not all biopsy cores show the BKVAN pathology; this is seen in approximately $30 \%$ of 
cases [79]. Therefore, it is recommended that two kidney tissue core samples be collected, at least one of which should contain medullary parenchyma [78]. Allograft biopsy can be skipped in patients with stable renal function because of the possibility of a falsenegative result; it should be considered primarily for those with worsening renal function or markers indicating an increased immunological risk, such as a highly sensitized status with panel reactive antibodies, the presence of donor-specific antibodies (DSAs), blood group incompatibility, retransplantation after graft loss due to BKVAN, or a history of acute rejection. When the typical histological findings are not observed despite a high plasma BKV load, a repeat diagnostic biopsy in a different part of the allograft should be considered.

The characteristic histological findings of BKVAN are interstitial inflammation rich in lymphocytes and plasma cells, intranuclear inclusions in tubular epithelial cells, smudgy nuclear chromatin, cellular atypia, and tubular epithelial cell degeneration, along with rounding, detachment, and apoptosis $[7,25,80]$. Cytopathic changes are more readily observed in the tubules of the medulla. Above all, detecting virus-infected tubular epithelial cells by immunohistochemical staining for SV40 large T-antigen is essential.

Nankivell et al. revealed that the principal driver of the BKVAN phenotype is direct tubular injury caused by the virus, with early acute antiviral responses amplifying the injury, followed by chronic active tubulointerstitial inflammation [80]. Note that it is sometimes difficult to distinguish the histological findings of BKVAN and acute T cellmediated rejection (TCMR) [81], although they differ in cell type [79,82,83], protein [79], proteomic [84], and gene expression profiles [85,86].

\subsection{Classification Systems}

Several classification systems have been proposed for determining the most appropriate treatment based on the severity of the disease, and for predicting the clinical outcome. Since no single histological finding reliably predicts the clinical outcome, they are combined. The AST and Banff classification systems are widely recognized.

The AST Infectious Disease Community of Practice published a composite system for staging BKVAN based on viral cytopathic changes, interstitial inflammation, tubular atrophy and interstitial fibrosis (Table 2) [14]. The AST classification semi-quantifies the histological findings into patterns A-C, which correspond to acute tubular injury, interstitial nephritis, and severe interstitial fibrosis, respectively. This system especially focuses on the presence of interstitial inflammation and subclassifies pattern B as B1-B3 based on the extent of inflammation. The reported risk of graft loss is $<10 \%$ in pattern $\mathrm{A}, 25 \%$ in $\mathrm{B} 1,50 \%$ in $\mathrm{B} 2,75 \%$ in $\mathrm{B} 3$, and $>80 \%$ in $\mathrm{C}$ [18].

Table 2. Histological grading of BKVAN-2013 AST classification.

\begin{tabular}{llll}
\hline & Pattern A & Pattern B & Pattern C \\
\hline Viral cytopathic changes & $\leq 25 \%$ & $11->50 \%$ & variable \\
Interstitial inflammation & $\leq 10 \%$ & $\mathrm{~B} 1 ; 11-25 \%$ & variable \\
& & $\mathrm{B} 2 ; 26-50 \%$ & \\
Tubular atrophy & $\leq 10 \%$ & $\mathrm{~B} 3 ;>50 \%$ & $>50 \%$ \\
Interstitial fibrosis & $\leq 10 \%$ & $<50 \%$ & $>50 \%$ \\
\hline
\end{tabular}

The Banff Working Group retrospectively analyzed patients with "definitive" BKVAN to identify factors associated with the clinical presentation, and found that two independent histological variables were significant: the intra-renal viral load (PyVL score) and the extent of interstitial fibrosis (ci score). They recently updated their classification system (Table 3) and reported graft failure rates of $16 \%, 31 \%$, and $50 \%$ in classes $1-3$, respectively [87]. Nickeleit et al. later validated the correlation between the Banff classification and clinical outcome of their recent patients [8]. In higher classes, the time between transplantation and BKVAN diagnosis was longer, the plasma BKV load increased, and peak and long-term 
serum creatinine levels increased. The graft failure rate was 5\%,30\%, and 50\% in classes $1-3$, respectively.

Table 3. Histological grading of BKVAN-2018 Banff classification.

\begin{tabular}{llllll}
\hline Class 1 & \multicolumn{3}{c}{ Class 2 3} \\
\hline PyVL & ci score & PyVL & ci score & PyVL & ci score \\
1 & $0-1$ & 1 & $2-3$ & - & - \\
- & - & 2 & $0-3$ & - & - \\
- & - & 3 & $0-1$ & 3 & $2-3$ \\
\hline
\end{tabular}

PyVL was semiquantitatively assigned based on the overall percentage of tubules in the cortex and medulla with morphologic evidence of polyomavirus replication. A tubule with intranuclear viral inclusion bodies (type 1 or 2) and/or a positive immunohistochemistry reaction for SV40 large T-antigen in one or more cells per tubular cross section is considered "a positive tubule." The overall percentage of positive tubular cross sections is estimated in the entire biopsy sample (all available cores, cortex, and medulla). PyVL score $1: \leq 1 \%$; PyVL score $2:>1 \%$ and $\leq 10 \%$; PyVL score $3:>10 \%$ positive tubules/ducts. ci score $0: \leq 5 \%$; ci score $1:>5 \%$ and $\leq 25 \%$; ci score $2:>25 \%$ and $\leq 50 \%$; ci score $3:>50 \%$ of interstitial fibrosis in cortical area.

\subsection{Immune Response}

Inflammatory cell infiltration into the renal allografts was probably the driving force for BKVAN progression. It has been reported that the infiltration of CD3+ (T-lymphocytes), CD4+ (helper T-lymphocytes), CD8+ (cytotoxic T-lymphocytes), CD20+ (B-lymphocytes), CD138+ (plasma cells), and CD68+ (macrophages) cells as well as IL-2R and HLA-DR expression increased with BKVAN progression [88]. T-cells play central roles in the initiation and progression of BKVAN, however, it remains unclear whether BKV responses are mediated predominantly by CD4+ or CD8+ T-lymphocytes, and in particular which subset plays a protective role in the control of the infection $[75,89,90]$. Large T-antigen preferentially stimulates CD8+ T-cells, whereas Vp1 preferentially stimulates CD4+ Tcells [89]. CD4+ T-cells have a specific polyfunctional antiviral effect on BKV infection by secreting interferon- $\gamma$, tumor necrosis factor- $\alpha$ and IL-2 [91]. B-cells and plasma cells also increase with concordant BKVAN progression $[79,88]$, suggesting that humoral immunity is involved in the immunological reaction against BKV.

\section{Prognostic Factors}

In addition to the above-mentioned histological factors included in the classification systems, the risk of graft loss was expected to be higher in cases with high-level viremia, renal dysfunction, deceased donor transplantation, and late acute rejection [79,80,82,92]. Especially, sustained viremia and SV40 large T-antigen positivity on the follow-up biopsy were frequently associated with allograft loss [93-95]. Meanwhile, an increase in BKVspecific T cells directed to BKV proteins (large T- and small $t$-antigen, and Vp1-3) was shown to predict successful control of BK viremia $[93,96,97]$. Recently, it was found that CD4+ T-cell exhaustion and the diversity of the antigen specific T-cell receptor repertoire affect the BKV clearance time [98].

\section{Treatment}

No specific anti-viral therapy has been developed to treat BKVAN. Thus, early treatment before the development of irreversible histopathological damage are important to ensure a favorable prognosis [25]. The AST guideline recommends starting interventions at the high-level BK viremia stage, which is indicative of probable or presumptive BKVAN [18].

\subsection{Therapeutic Options}

Since no BKV-specific antiviral therapy has been developed, reducing the level of maintenance immunosuppression is the most common and effective treatment for BK viremia or BKVAN. Currently, the AST guideline recommends two strategies [18]: (i) first reduce the dose of the calcineurin inhibitor by $25-50 \%$ in one or two steps, and then reduce 
by $50 \%$ and ultimately discontinue the antimetabolites; (ii) first reduce the antimetabolites by $50 \%$, and then reduce the calcineurin inhibitors by $25-50 \%$ and discontinue the antimetabolites. At this time, the "calcineurin inhibitor first" and "antimetabolite first" approaches (as the first step) are considered largely equivalent $[6,41,43,99,100]$. There is in vitro evidence that tacrolimus inhibits anti-BK-specific T cells, which are necessary for viral clearance. Bischof et al. found that reducing the calcineurin inhibitor first in viremia patients led to similar long-term outcomes and clinical rejection rates to those of patients without viremia [99]. They succeeded in clearing the virus from the plasma by reducing tacrolimus in $39 \%$ of cases, in another $43 \%$ by also reducing mycophenolate, and in $3 \%$ by discontinuing mycophenolate (total $=96 \%$ ). Some centers reduce the antimetabolite first, whereas others discontinue it [6,41]. Hardinger et al. discontinued the antimetabolite first and found that BKV disappeared from the plasma in $95 \%$ of viremia patients; half of the patients discontinued the antimetabolite and the other half with sustained viremia also reduced the calcineurin inhibitor [100]. Alternatively, simultaneous dose reduction of both the calcineurin inhibitor and antimetabolite can be considered in severe BKVAN.

Commonly targeted trough levels are tacrolimus $<6 \mathrm{ng} / \mathrm{mL}$, cyclosporine $<150 \mathrm{ng} / \mathrm{mL}$, and sirolimus $<6 \mathrm{ng} / \mathrm{mL}$. Further stepwise reductions may be appropriate in select patients, including those with more advanced disease; in such cases, trough levels of tacrolimus $<3 \mathrm{ng} / \mathrm{mL}$ and cyclosporine $<100 \mathrm{ng} / \mathrm{mL}$ are targeted [18]. To determine how much immunosuppression reduction is required, clinicians must consider the patient's immunologic risk, the viral load, and the degree of kidney impairment.

Other options are switching tacrolimus to cyclosporine, switching the calcineurin inhibitor to sirolimus or everolimus, and switching mycophenolate to leflunomide, mizoribine, or everolimus [101-104].

In addition, several medical treatments have been tried, including intravenous immunoglobulin [105,106], cidofovir [107,108], and fluoroquinolone [109]. Intravenous immunoglobulin through osmotic injury causes vacuolation in proximal tubular epithelial cells, in turn leading to acute kidney injury [110]. Cidofovir is nephrotoxic and has less potent anti-BKV activity than the other therapies [108]. Fluoroquinolone has gastrointestinal and central nervous system side effects [111]. None of these treatments have sufficient clinical data supporting their use as standard practices.

BKVAN sometimes accompanies acute rejection; these cases are difficult to treat. In cases of sustained BK viremia with biopsy-proven acute rejection (with or without evidence of concurrent BKVAN), antirejection treatment should be given first, and immunosuppression reduction should be considered as a second step (e.g., after two weeks). Acute rejection should be diagnosed according to the Banff criteria, while recognizing that tubulitis and peritubular inflammation may also be observed in BKVAN [112,113].

\subsection{Treatment Goal}

During the first two months after diagnosis and reduction of immunosuppression, the serum creatinine levels increase temporally, and tubulointerstitial inflammation worsens in re-biopsy tissues $[94,95]$. Such increased inflammation (immune reconstitution) clears BKV from the allograft kidney $[87,94,95]$.

The definition of 'resolution' is controversial. Some studies define it as the disappearance of SV40 large T-antigen positive cells on a follow-up biopsy and/or negative BK viremia $[87,92,95]$. However, as the histological changes caused by BKV are seen only in patches of the transplanted kidney, negative viral staining does not always mean the BKVAN has been cured. It is desirable that treatments be continued until there is continuous clearance of plasma BKV DNA. Even then, BK viremia recurs in approximately $10 \%$ of patients, who may require an additional reduction of immunosuppression [42,99]. When the immunosuppressant is reduced at the viremia stage, the reported BKV clearance rate is $80-100 \%[43,99,114]$, meanwhile, in biopsy-proven BKVAN, the viral clearance rate is lower [114]. In such cases, an additional reduction in immunosuppression over a longer period may be necessary, but treatments sometimes fails resulting in allograft loss. 


\subsection{Treatment-Associated Allograft Rejection}

There is concern that reducing immunosuppression can lead to TCMR and antibodymediated rejection (ABMR). The reported incidence of TCMR is 4.3-14.6\% [99,115]. Cheungpasitporn et al. reported that de novo DSA developed in $14 \%$ of cases within 14 months of BKVAN diagnosis [116]. These patients had a higher risk of ABMR (hazard ratio 4.75) and allograft loss (hazard ratio 2.63). Other studies demonstrated that BKVAN ultimately resulted in allograft loss in 15-38\% of patients; in half of those patients the cause was rejection after immunosuppression reduction rather than uncontrolled viral infection $[7,41,80,115]$.

If the clinical signs of allograft rejection are recognized, such as an acute or progressive rise in serum creatinine despite declining viremia, an allograft biopsy is necessary to determine whether there is concomitant rejection [115]. In such cases, a carefully managed increase in maintenance immunosuppression should be considered, with frequent monitoring of plasma BKV DNA. Treatment response of acute rejection to steroid administration ranges from $40 \%$ to $100 \%[43,117]$. When acute ABMR is present, administration of rituximab and plasmapheresis may have to be considered.

\subsection{Immunosuppressant Resumption}

When viral DNA continuously disappears from the plasma on reducing immunosuppression, a return to the baseline level might be required to avoid chronic allograft rejection. There is no consensus on whether a re-increase to the standard dose can prevent subsequent rejection, nor on what drugs should be used, what trough levels should be targeted, and how long viremia should be absent for. Alquadan et al. reported their immunosuppression resumption protocol, which was used in 36 patients with BK viremia [118]. After four weeks of no viremia, they increased mycophenolate by $500 \mathrm{mg} /$ day every 2 two weeks up to the standard dose, and then increased the tacrolimus trough levels to $5-7 \mathrm{ng} / \mathrm{mL}$. If viremia recurred during the increase, immunosuppression was reduced again, and then increased stepwise after two months of negative viremia. Only one patient developed low-level viremia, which ultimately resolved. Long-term immunosuppression management after viremia clearance or resolution of BKVAN is individualized based on the balance between the patient's immunologic risk and the risk of BKV re-activation.

\section{Retransplantation}

Retransplantation is not contraindicated for those who experienced graft failure due to BKVAN. Dharnidharka et al. reported that 126 of 823 kidney recipients were retransplanted after loss of the prior allograft due to BKVAN [119]. The induction and maintenance immunosuppression regimens at retransplantation were similar to those for the first-time; the one- and three-year graft survival rates in retransplanted recipients were $99 \%$ and $94 \%$, respectively. Treatment for BKV was reported in $17.5 \%$ of retransplanted patients, while graft loss due to recurrent BKVAN was seen in one patient. Leeaphorn et al. compared the clinical outcome of retransplantation in 341 patients who had first graft failure due to BKVAN and 13,260 patients with graft failure for other reasons [120]. The five-year death-censored graft survival rate for the second renal allograft was $90.6 \%$ in the BK group and $83.9 \%$ in the non-BK group.

There is a consensus that BK viremia should be cleared before retransplantation to minimize recurrence $[6,14,41,119,121]$. In retransplanted patients with persistent BK viremia, a significant decline of at least $2 \log _{10} \mathrm{c} / \mathrm{mL}$ is desirable [122].

Surgical removal of the prior transplanted kidney is not necessary at the time of retransplantation, because it does not prevent recurrent BKV replication or BKVAN. However, since BKV-infected allograft nephrectomy rapidly clears BKV from the plasma $\left(t_{1 / 2}\right.$, hours to two days) [123], it is an option in cases of uncontrolled BKV replication [122]. Nephrectomy of native kidneys, which remains a reservoir and source of reinfection, is not generally performed. For retransplanted recipients after loss of the prior allograft due to BKVAN, more intense monitoring for BKV replication than usual would be required. 


\section{Conclusions}

BKVAN is a threatening complication of renal transplantation. Since early diagnosis and therapeutic management are important, regular screening is highly recommended. Allograft biopsy is required for definitive diagnosis in cases with renal dysfunction, and histological classification systems are useful to predict the therapeutic outcomes. Due to the lack of effective anti-viral drugs, the main therapeutic strategy is to reduce immunosuppression; at the same time, clinicians must pay attention to the risk of allograft rejection.

Funding: This research received no external funding.

Institutional Review Board Statement: Not applicable.

Informed Consent Statement: Not applicable.

Conflicts of Interest: The author declares no conflict of interest.

$\begin{array}{ll}\text { Abbreviations } \\ \text { BKV } & \text { BK virus } \\ \text { BKVAN } & \text { BK virus-associated nephropathy } \\ \text { KDIGO } & \text { Kidney Disease: Improving Global Outcomes } \\ \text { AST } & \text { American Society of Transplantation } \\ \text { TCMR } & \text { T cell-mediated rejection } \\ \text { SV40 } & \text { Simian virus 40 } \\ \text { ABMR } & \text { Antibody-mediated rejection } \\ \text { DSA } & \text { Donor-specific antibody }\end{array}$

\section{References}

1. Purighalla, R.; Shapiro, R.; McCauley, J.; Randhawa, P. BK virus infection in a kidney allograft diagnosed by needle biopsy. Am. J. Kidney Dis. Off. J. National Kidney Found. 1995, 26, 671-673. [CrossRef]

2. Cai, X.; Chang, D.; Rottinghaus, S.; Consigi, R.A. Expression and purification of recombinant polyomavirus VP2 protein and its interactions with polyomavirus proteins. J. Virol. 1994, 68, 609-613. [CrossRef] [PubMed]

3. Hirsch, H.H.; Steiger, J. Polyomavirus BK. Lancet Infect. Dis. 2003, 3, 611-623. [CrossRef]

4. Antonsson, A.; Pawlita, M.; Feltkamp, M.C.; Bouwes Bavinck, J.N.; Euvrard, S.; Harwood, C.A.; Naldi, L.; Nindl, I.; Proby, C.M.; Neale, R.E.; et al. Prevalence and stability of antibodies to the BK and JC polyomaviruses: A long-term longitudinal study of Australians. J Gen. Virol. 2010, 91, 1849-1853. [CrossRef] [PubMed]

5. Antonsson, A.; Pawlita, M.; Feltkamp, M.C.; Bouwes Bavinck, J.N.; Euvrard, S.; Harwood, C.A.; Naldi, L.; Nindl, I.; Proby, C.M.; Neale, R.E.; et al. Longitudinal study of seroprevalence and serostability of the human polyomaviruses JCV and BKV in organ transplant recipients. J. Med. Virol. 2013, 85, 327-335. [CrossRef]

6. Hirsch, H.H.; Brennan, D.C.; Drachenberg, C.B.; Ginevri, F.; Gordon, J.; Limaye, A.P.; Mihatsch, M.J.; Nickeleit, V.; Ramos, E.; Randhawa, P.; et al. Polyomavirus-associated nephropathy in renal transplantation: Interdisciplinary analyses and recommendations. Transplantation 2005, 79, 1277-1286. [CrossRef]

7. Drachenberg, C.B.; Papadimitriou, J.C.; Chaudhry, M.R.; Ugarte, R.; Mavanur, M.; Thomas, B.; Cangro, C.; Costa, N.; Ramos, E.; Weir, M.R.; et al. Histological Evolution of BK Virus-Associated Nephropathy: Importance of Integrating Clinical and Pathological Findings. Am. J. Transpl. Off. J. Am. Soc. Transpl. Am.Soc. Transpl. Surg. 2017, 17, 2078-2091. [CrossRef]

8. Nickeleit, V.; Singh, H.; Dadhania, D.; Cornea, V.; El-Husseini, A.; Castellanos, A.; Davis, V.; Waid, T.; Seshan, S. The 2018 Banff Working Group classification of definitive polyomavirus nephropathy: A multicenter validation study in the modern era. Am. J. Transpl. Off. J. Am. Soc. Transpl. Am. Soc. Transpl. Surg. in press. [CrossRef]

9. Johnston, O.; Jaswal, D.; Gill, J.S.; Doucette, S.; Fergusson, D.A.; Knoll, G.A. Treatment of polyomavirus infection in kidney transplant recipients: A systematic review. Transplantation 2010, 89, 1057-1070. [CrossRef]

10. Hsieh, M.C.; Hung, C.W.; Chiou, H.L.; Yang, S.F. Effect of a BK viruria reaction detected by qualitative polymerase chain reaction on the renal function of kidney transplant recipients. Mol. Med. Rep. 2013, 7, 1319-1323. [CrossRef]

11. Funahashi, Y.; Kato, M.; Fujita, T.; Takai, S.; Kimura, Y.; Gotoh, M. Prevalence of polyomavirus positivity in urine after renal transplantation. Transpl. Proc. 2014, 46, 564-566. [CrossRef] [PubMed]

12. Saundh, B.K.; Tibble, S.; Baker, R.; Sasnauskas, K.; Harris, M.; Hale, A. Different patterns of BK and JC polyomavirus reactivation following renal transplantation. J. Clin. Pathol. 2010, 63, 714-718. [CrossRef] [PubMed]

13. Masutani, K.; Shapiro, R.; Basu, A.; Tan, H.; Ninomiya, T.; Randhawa, P. Putative episodes of T-cell-mediated rejection in patients with sustained BK viruria but no viremia. Transplantation 2012, 94, 43-49. [PubMed] 
14. Hirsch, H.H.; Randhawa, P.; AST Infectious Diseases Community of Practice. BK polyomavirus in solid organ transplantationGuidelines from the American Society of Transplantation Infectious Iseases Disease Community of Practice. Am. J. Transpl. Off. J. Am. Soc. Transpl. Am. Soc. Transpl. Surg. 2013, 13, 179-188. [CrossRef] [PubMed]

15. Pakfetrat, M.; Yaghobi, R.; Salmanpoor, Z.; Roozbeh, J.; Torabinezhad, S.; Kadkhodaei, S. Frequency of Polyomavirus BK Infection in Kidney Transplant Patients Suspected to Nephropathy. Int. J. Organ Transpl. Med. 2015, 6, 77-84.

16. Boan, P.; Hewison, C.; Swaminathan, R.; Irish, A.; Warr, K.; Sinniah, R.; Pryce, T.M.; Flexman, J. Optimal use of plasma and urine BK viral loads for screening and predicting BK nephropathy. BMC Infect. Dis. 2016, 16, 342. [CrossRef] [PubMed]

17. Xiong, R.; Ye, H.; Liu, Z.; Li, X. Incidence and risk factors for high-level BK viruria: A single center study in China. Virol. J. 2020, 17, 189. [CrossRef]

18. Hirsch, H.H.; Randhawa, P.S.; AST Infectious Diseases Community of Practice. BK polyomavirus in solid organ transplantationGuidelines from the American Society of Transplantation Infectious Diseases Community of Practice. Clin. Transpl. 2019, 33, e13528. [CrossRef]

19. Mallat, S.G.; Tanios, B.Y.; Itani, H.S.; Lotfi, T.; McMullan, C.; Gabardi, S.; Akl, E.A.; Azzi, J.R. CMV and BKPyV Infections in Renal Transplant Recipients Receiving an mTOR Inhibitor-Based Regimen Versus a CNI-Based Regimen: A Systematic Review and Meta-Analysis of Randomized, Controlled Trials. Clin. J. Am. Soc. Nephrol. CJASN 2017, 12, 1321-1336.

20. Moscarelli, L.; Caroti, L.; Antognoli, G.; Zanazzi, M.; Di Maria, L.; Carta, P.; Minetti, E. Everolimus leads to a lower risk of BKV viremia than mycophenolic acid in de novo renal transplantation patients: A single-center experience. Clin. Transpl. 2013, 27, 546-554.

21. Schold, J.D.; Rehman, S.; Kayle, L.K.; Magliocca, J.; Srinivas, T.R.; Meier-Kriesche, H.U. Treatment for BK virus: Incidence, risk factors and outcomes for kidney transplant recipients in the United States. Transpl Int. Off. J. Eur. Soc. Organ Transpl. 2009, 22, 626-634. [CrossRef]

22. Schwarz, A.; Linnenweber-Held, S.; Heim, A.; Framke, T.; Haller, H.; Schmitt, C. Viral Origin, Clinical Course, and Renal Outcomes in Patients With BK Virus Infection After Living-Donor Renal Transplantation. Transplantation 2016, 100, 844-853. [CrossRef] [PubMed]

23. Brochot, E.; Descamps, V.; Handala, L.; Faucher, J.; Choukroun, G.; Helle, F.; Castelain, S.; Francois, C.; Duverlie, G.; Touze, A. BK polyomavirus in the urine for follow-up of kidney transplant recipients. Clin. Microbiol. Infect. Off. Publ. Eur. Soc. Clin. Microbiol. Infect. Dis. 2019, 25, 112.e1-112.e5. [CrossRef] [PubMed]

24. Bohl, D.L.; Brennan, D.C.; Ryschkewitsch, C.; Gaudreault-Keener, M.; Major, E.O.; Storch, G.A. BK virus antibody titers and intensity of infections after renal transplantation. J. Clin. Virol. Off. Publ. Pan Am. Soc. Clin. Virol. 2008, 43, 184-189. [CrossRef] [PubMed]

25. Hirsch, H.H.; Knowles, W.; Dickenmann, M.; Passweg, J.; Klimkait, T.; Mihatsch, M.J.; Steiger, J. Prospective study of polyomavirus type BK replication and nephropathy in renal-transplant recipients. N. Engl. J. Med. 2002, 347, 488-496. [CrossRef]

26. Teutsch, K.; Schweitzer, F.; Knops, E.; Kaiser, R.; Pfister, H.; Verheyen, J.; Gobel, H.; Cingoz, T.; Di Cristanziano, V. Early identification of renal transplant recipients with high risk of polyomavirus-associated nephropathy. Med. Microbiol. Immunol. 2015, 204, 657-664. [CrossRef]

27. Rohn, H.; Schwich, E.; Tomoya Michita, R.; Schramm, S.; Dolff, S.; Gackler, A.; Korth, J.; Heinemann, F.M.; Wilde, B.; Trilling, M.; et al. HLA-G $3^{\prime}$ untranslated region gene variants are promising prognostic factors for BK polyomavirus replication and acute rejection after living-donor kidney transplant. Hum. Immunol. 2020, 81, 141-146.

28. Bohl, D.L.; Storch, G.A.; Ryschkewitsch, C.; Gaudreault-Keener, M.; Schnitzler, M.A.; Major, E.O.; Brennan, D.C. Donor origin of BK virus in renal transplantation and role of HLA C7 in susceptibility to sustained BK viremia. Am. J. Transpl. Off. J. Am. Soc. Transpl. Am. Soc. Transpl. Surg. 2005, 5, 2213-2221. [CrossRef]

29. Kovacevic Vojtusek, I.; Burek Kamenaric, M.; Ivkovic, V.; Bulimbasic, S.; Marekovic, I.; Coric, M.; Bosnjak, Z.; Grubic, Z.; Zunec, R. Combined association of recipient killer cell immunoglobulin-like haplotype AA and donor HLA-C*07 gene with BK virus associated nephropathy in kidney transplant patients. Hla 2019, 94, 4-10. [CrossRef]

30. Sharif, A.; Alachkar, N.; Bagnasco, S.; Geetha, D.; Gupta, G.; Womer, K.; Arend, L.; Racusen, L.; Montgomery, R.; Kraus, E. Incidence and outcomes of BK virus allograft nephropathy among ABO- and HLA-incompatible kidney transplant recipients. Clin. J. Am. Soc. Nephrol. CJASN 2012, 7, 1320-1327. [CrossRef]

31. Shenagari, M.; Monfared, A.; Eghtedari, H.; Pourkazemi, A.; Hasandokht, T.; Khosravi, M.; Asharfkhani, B. BK virus replication in renal transplant recipients: Analysis of potential risk factors may contribute in reactivation. J. Clin. Virol. Off. Publ. Pan Am. Soc. Clin. Virol. 2017, 96, 7-11. [CrossRef] [PubMed]

32. Theodoropoulos, N.; Wang, E.; Penugonda, S.; Ladner, D.P.; Stosor, V.; Leventhal, J.; Friedewald, J.; Angarone, M.P.; Ison, M.G. BK virus replication and nephropathy after alemtuzumab-induced kidney transplantation. Am. J. Transpl. Off. J. Am. Soc. Transpl. Am. Soc. Transpl. Surg. 2013, 13, 197-206. [CrossRef] [PubMed]

33. Wunderink, H.F.; Haasnoot, G.W.; de Brouwer, C.S.; van Zwet, E.W.; Kroes, A.C.M.; de Fijter, J.W.; Rotmans, J.I.; Claas, F.H.J.; Feltkamp, M.C.W. Reduced Risk of BK Polyomavirus Infection in HLA-B51-positive Kidney Transplant Recipients. Transplantation 2019, 103, 604-612. [PubMed]

34. Elfadawy, N.; Flechner, S.M.; Liu, X.; Schold, J.; Srinivas, T.R.; Poggio, E.; Fatica, R.; Avery, R.; Mossad, S.B. CMV Viremia is associated with a decreased incidence of BKV reactivation after kidney and kidney-pancreas transplantation. Transplantation 2013, 96, 1097-1103. [CrossRef] 
35. Jacobi, J.; Prignitz, A.; Buttner, M.; Korn, K.; Weidemann, A.; Hilgers, K.F.; Heller, K.; Velden, J.; Knoll, A.; Wullich, B.; et al. BK viremia and polyomavirus nephropathy in 352 kidney transplants; risk factors and potential role of mTOR inhibition. BMC Nephrol. 2013, 14, 207. [CrossRef]

36. Mindlova, M.; Boucek, P.; Saudek, F.; Skibova, J.; Jedinakova, T.; Lipar, K.; Adamec, M.; Hirsch, H.H. Prevalence and risk factors of polyomavirus BK replication in simultaneous pancreas/kidney transplant recipients from a single transplant center. Clin. Trans. 2012, 26, 267-274. [CrossRef]

37. Hsiao, C.Y.; Pilmore, H.L.; Zhou, L.; de Zoysa, J.R. Outcomes of renal transplant recipients with BK virus infection and BK virus surveillance in the Auckland region from 2006 to 2012. World J. Nephrol. 2016, 5, 497-506.

38. Manitpisitkul, W.; Drachenberg, C.; Ramos, E.; Munivenkatappa, R.; Philosophe, B.; Klassen, D.; Haririan, A. Maintenance immunosuppressive agents as risk factors for BK virus nephropathy: A case-control study. Transplantation 2009, 88, 83-88. [CrossRef]

39. Hirsch, H.H.; Vincenti, F.; Friman, S.; Tuncer, M.; Citterio, F.; Wiecek, A.; Scheuermann, E.H.; Klinger, M.; Russ, G.; Pescovitz, M.D.; et al. Polyomavirus BK replication in de novo kidney transplant patients receiving tacrolimus or cyclosporine: A prospective, randomized, multicenter study. Am. J. Transpl. Off. J. Am. Soc. Transpl. Am. Soc. Transpl. Surg. 2013, 13, 136-145. [CrossRef]

40. Siparsky, N.F.; Kushnir, L.F.; Gallichio, M.H.; Conti, D.J. Ureteral stents: A risk factor for polyomavirus BK viremia in kidney transplant recipients undergoing protocol screening. Transpl. Proc. 2011, 43, 2641-2644. [CrossRef]

41. Hirsch, H.H.; Babel, N.; Comoli, P.; Friman, V.; Ginevri, F.; Jardine, A.; Lautenschlager, I.; Legendre, C.; Midtvedt, K.; Munoz, P.; et al. European perspective on human polyomavirus infection, replication and disease in solid organ transplantation. Clin. Microbiol. Infect. Off. Publ. Eur. Soc. Clin. Microbiol. Infect. Dis. 2014, 20, 74-88. [CrossRef] [PubMed]

42. Huang, G.; Wang, C.X.; Zhang, L.; Fei, J.G.; Deng, S.X.; Qiu, J.; Li, J.; Chen, G.D.; Fu, Q.; Chen, L.Z. Monitoring of polyomavirus BK replication and impact of preemptive immunosuppression reduction in renal-transplant recipients in China: A 5-year single-center analysis. Diagn. Microbiol. Infect. Dis. 2015, 81, 21-26. [CrossRef] [PubMed]

43. Schaub, S.; Hirsch, H.H.; Dickenmann, M.; Steiger, J.; Mihatsch, M.J.; Hopfer, H.; Mayr, M. Reducing immunosuppression preserves allograft function in presumptive and definitive polyomavirus-associated nephropathy. Am. J. Transpl. Off. J. Am. Soc. Transpl. Am. Soc. Transpl. Surg. 2010, 10, 2615-2623. [CrossRef] [PubMed]

44. Hocker, B.; Schneble, L.; Murer, L.; Carraro, A.; Pape, L.; Kranz, B.; Oh, J.; Zirngibl, M.; Dello Strologo, L.; Buscher, A.; et al. Epidemiology of and Risk Factors for BK Polyomavirus Replication and Nephropathy in Pediatric Renal Transplant Recipients: An International CERTAIN Registry Study. Transplantation 2019, 103, 1224-1233. [CrossRef]

45. Funahashi, Y.; Kato, M.; Fujita, T.; Tsuruta, K.; Inoue, S.; Gotoh, M. Correlation between urine and serum BK virus levels after renal transplantation. Transpl. Proc. 2014, 46, 567-569. [CrossRef] [PubMed]

46. Viscount, H.B.; Eid, A.J.; Espy, M.J.; Griffin, M.D.; Thomsen, K.M.; Harmsen, W.S.; Razonable, R.R.; Smith, T.F. Polyomavirus polymerase chain reaction as a surrogate marker of polyomavirus-associated nephropathy. Transplantation 2007, 84, 340-345. [CrossRef]

47. Eckardt, K.U.; Kasiske, B.L. Kidney disease: Improving global outcomes. Nat. Rev. Nephrol. 2009, 5, 650-657. [CrossRef]

48. Hodowanec, A.C.; Simon, D.M. BK virus screening and management practices among US renal transplant programs: A survey. Transpl. Int. Off. J. Eur. Soc. Organ. Transpl. 2015, 28, 1339-1341. [CrossRef]

49. Pape, L.; Tonshoff, B.; Hirsch, H.H. Members of the Working Group 'Transplantation' of the European Society for Paediatric, N. Perception, diagnosis and management of BK polyomavirus replication and disease in paediatric kidney transplant recipients in Europe. Nephrol. Dial. Trans. Off. Publ. Eur. Dial. Transpl. Assoc. Eur. Ren. Assoc. 2016, 31, 842-847.

50. Bicalho, C.S.; Oliveira, R.D.R.; David, D.R.; Fink, M.; Agena, F.; Castro, M.C.; Panutti, C.; David-Neto, E.; Pierrotti, L.C. Determination of viremia cut-off for risk to develop BKPyV-associated nephropathy among kidney transplant recipients. Transpl. Infect. Dis. Off. J. Transpl. Soc. 2018, 20, e12969. [CrossRef]

51. Saundh, B.K.; Baker, R.; Harris, M.; Welberry Smith, M.P.; Cherukuri, A.; Hale, A. Early BK polyomavirus (BKV) reactivation in donor kidney is a risk factor for development of BKV-associated nephropathy. J. Infect. Dis. 2013, 207, 137-141. [CrossRef] [PubMed]

52. Randhawa, P.; Ho, A.; Shapiro, R.; Vats, A.; Swalsky, P.; Finkelstein, S.; Uhrmacher, J.; Weck, K. Correlates of quantitative measurement of BK polyomavirus (BKV) DNA with clinical course of BKV infection in renal transplant patients. J. Clin. Microbiol. 2004, 42, 1176-1180. [CrossRef] [PubMed]

53. Pang, X.L.; Doucette, K.; LeBlanc, B.; Cockfield, S.M.; Preiksaitis, J.K. Monitoring of polyomavirus BK virus viruria and viremia in renal allograft recipients by use of a quantitative real-time PCR assay: One-year prospective study. J. Clin. Microbiol. 2007, 45, 3568-3573. [CrossRef] [PubMed]

54. Egli, A.; Infanti, L.; Dumoulin, A.; Buser, A.; Samaridis, J.; Stebler, C.; Gosert, R.; Hirsch, H.H. Prevalence of polyomavirus BK and JC infection and replication in 400 healthy blood donors. J. Infect Dis. 2009, 199, 837-846. [CrossRef] [PubMed]

55. Grellier, J.; Hirsch, H.H.; Mengelle, C.; Esposito, L.; Hebral, A.L.; Belliere, J.; Weissbach, F.; Izopet, J.; Del Bello, A.; Kamar, N. Impact of donor BK polyomavirus replication on recipient infections in living donor transplantation. Transplant. Infect. Dis. Off. J. Transpl. Soc. 2018, 20, e12917. [CrossRef]

56. Tan, S.K.; Huang, C.; Sahoo, M.K.; Weber, J.; Kurzer, J.; Stedman, M.R.; Concepcion, W.; Gallo, A.E.; Alonso, D.; Srinivas, T.; et al. Impact of Pretransplant Donor BK Viruria in Kidney Transplant Recipients. J. Infect. Dis. 2019, 220, 370-376. [CrossRef] 
57. Verghese, P.S.; Schmeling, D.O.; Filtz, E.A.; Matas, A.J.; Balfour, H.H., Jr. The impact of recipient BKV shedding before transplant on BKV viruria, DNAemia, and nephropathy post-transplant: A prospective study. Pediatr. Transpl. 2017, 21, e12942. [CrossRef]

58. Nankivell, B.J.; Renthawa, J.; Jeoffreys, N.; Kable, K.; O'Connell, P.J.; Chapman, J.R.; Wong, G.; Sharma, R.N. Clinical Utility of Urinary Cytology to Detect BK Viral Nephropathy. Transplantation 2015, 99, 1715-1722. [CrossRef]

59. Koukoulaki, M.; O’Donovan, M.; Pursglove, S.; Alexopoulou, D.; Hadjiconstantinou, V.; Drakopoulos, S. Prospective study of urine cytology screening for BK polyoma virus replication in renal transplant recipients. Cytopathology 2008, 19, 385-388. [CrossRef]

60. Cimbaluk, D.; Pitelka, L.; Kluskens, L.; Gattuso, P. Update on human polyomavirus BK nephropathy. Diagn Cytopathol. 2009, 37, 773-779. [CrossRef]

61. Ariyasu, S.; Yanai, H.; Sato, M.; Shinno, Y.; Taniguchi, K.; Yamadori, I.; Miki, Y.; Sato, Y.; Yoshino, T.; Takahashi, K. Simultaneous immunostaining with anti-S100P and anti-SV40 antibodies revealed the origin of BK virus-infected decoy cells in voided urine samples. Cytopathology 2015, 26, 250-255. [CrossRef] [PubMed]

62. Funahashi, Y.; Kato, M.; Fujita, T.; Ishida, S.; Mori, A.; Gotoh, M. Association Between the Polyomaviruses Titers and Decoy Cell Positivity Rates After Renal Transplantation. Transpl. Proc. 2016, 48, 921-923. [CrossRef] [PubMed]

63. Drachenberg, C.B.; Hirsch, H.H.; Papadimitriou, J.C.; Gosert, R.; Wali, R.K.; Munivenkatappa, R.; Nogueira, J.; Cangro, C.B.; Haririan, A.; Mendley, S.; et al. Polyomavirus BK versus JC replication and nephropathy in renal transplant recipients: A prospective evaluation. Transplantation 2007, 84, 323-330. [CrossRef] [PubMed]

64. Funahashi, Y.; Iwata, S.; Ito, Y.; Kojima, S.; Yoshikawa, T.; Hattori, R.; Gotoh, M.; Nishiyama, Y.; Kimura, H. Multiplex real-time PCR assay for simultaneous quantification of BK polyomavirus, JC polyomavirus, and adenovirus DNA. J. Clin. Microbiol. 2010, 48, 825-830. [CrossRef] [PubMed]

65. de Assis, P.G.; de Souza Carvalho, C.E.; Soares da Mota, E.S.M.; da Costa Carvalho, M.D.G. DNA detection of JC and BK virus in archival urine cytospin slides. J. Med. Virol. 2018, 90, 599-603. [CrossRef]

66. Koh, M.J.; Lim, B.J.; Noh, S.; Kim, Y.H.; Jeong, H.J. Urinary decoy cell grading and its clinical implications. Korean J. Pathol. 2012, 46, 233-236. [CrossRef] [PubMed]

67. Singh, H.K.; Reisner, H.; Derebail, V.K.; Kozlowski, T.; Nickeleit, V. Polyomavirus nephropathy: Quantitative urinary polyomavirus-Haufen testing accurately predicts the degree of intrarenal viral disease. Transplantation 2015, 99, 609-615. [CrossRef]

68. Singh, H.K.; Andreoni, K.A.; Madden, V.; True, K.; Detwiler, R.; Weck, K.; Nickeleit, V. Presence of urinary Haufen accurately predicts polyomavirus nephropathy. J. Am. Soc. Nephrol. 2009, 20, 416-427. [CrossRef]

69. Astegiano, S.; Bergallo, M.; Terlizzi, M.E.; Sidoti, F.; Gambarino, S.; Messina, M.; Costa, C.; Segoloni, G.P.; Cavallo, R. Combined measurement of serum DNA and urine VP1 messenger RNA in monitoring BK virus replication in kidney graft recipients. Transp. Proc. 2011, 43, 1052-1054. [CrossRef]

70. Konietzny, R.; Fischer, R.; Ternette, N.; Wright, C.A.; Turney, B.W.; Chakera, A.; Hughes, D.; Kessler, B.M.; Pugh, C.W. Detection of BK virus in urine from renal transplant subjects by mass spectrometry. Clin. Proteom. 2012, 9, 4. [CrossRef]

71. Maehana, T.; Tanaka, T.; Kitamura, H.; Fukuzawa, N.; Ishida, H.; Harada, H.; Tanabe, K.; Masumori, N. Heat Shock Protein 90alpha Is a Potential Serological Biomarker of Acute Rejection after Renal Transplantation. PLoS ONE 2016, 11, e0162942. [CrossRef] [PubMed]

72. Tinel, C.; Devresse, A.; Vermorel, A.; Sauvaget, V.; Marx, D.; Avettand-Fenoel, V.; Amrouche, L.; Timsit, M.O.; Snanoudj, R.; Caillard, S.; et al. Development and validation of an optimized integrative model using urinary chemokines for noninvasive diagnosis of acute allograft rejection. Am. J. Transpl. Off. J. Am. Soc. Transpl. Am. Soc. Transpl. Surg. 2020, 20, 3462-3476. [CrossRef] [PubMed]

73. Rau, S.; Schonermarck, U.; Jager, G.; Stangl, M.; Guba, M.; Meiser, B.; Fischereder, M.; Habicht, A. BK virus-associated nephropathy: Neutrophil gelatinase-associated lipocalin as a new diagnostic tool? Clin. Transpl. 2013, 27, E184-E191. [CrossRef] [PubMed]

74. Matsuda, Y.; Qazi, Y.; Iwaki, Y. A rapid and efficient method BK polyomavirus genotyping by high-resolution melting analysis. J. Med. Virol. 2011, 83, 2128-2134. [CrossRef]

75. Zhou, W.; Sharma, M.; Martinez, J.; Srivastava, T.; Diamond, D.J.; Knowles, W.; Lacey, S.F. Functional characterization of BK virus-specific CD4+ T cells with cytotoxic potential in seropositive adults. Viral Immunol. 2007, 20, 379-388. [CrossRef]

76. Kim, M.H.; Lee, Y.H.; Seo, J.W.; Moon, H.; Kim, J.S.; Kim, Y.G.; Jeong, K.H.; Moon, J.Y.; Lee, T.W.; Ihm, C.G.; et al. Urinary exosomal viral microRNA as a marker of BK virus nephropathy in kidney transplant recipients. PLoS ONE 2017, 12, e0190068. [CrossRef]

77. Gonzalez, S.; Escobar-Serna, D.P.; Suarez, O.; Benavides, X.; Escobar-Serna, J.F.; Lozano, E. BK Virus Nephropathy in Kidney Transplantation: An Approach Proposal and Update on Risk Factors, Diagnosis, and Treatment. Transpl. Proc. 2015, 47, 1777-1785. [CrossRef]

78. Nankivell, B.J.; Renthawa, J.; Shingde, M.; Khan, A. The Importance of Kidney Medullary Tissue for the Accurate Diagnosis of BK Virus Allograft Nephropathy. Clin. J. Am. Soc. Nephrol. CJASN 2020, 15, 1015-1023. [CrossRef]

79. Drachenberg, C.B.; Papadimitriou, J.C.; Hirsch, H.H.; Wali, R.; Crowder, C.; Nogueira, J.; Cangro, C.B.; Mendley, S.; Mian, A.; Ramos, E. Histological patterns of polyomavirus nephropathy: Correlation with graft outcome and viral load. Am. J. Transpl. Off. J. Am. Soc. Transpl. Am. Soc. Transpl. Surg. 2004, 4, 2082-2092. [CrossRef] 
80. Nankivell, B.J.; Renthawa, J.; Sharma, R.N.; Kable, K.; O'Connell, P.J.; Chapman, J.R. BK Virus Nephropathy: Histological Evolution by Sequential Pathology. Am. J. Transpl. Off. J. Am. Soc. Transpl. Am. Soc. Transpl. Surg. 2017, 17, 2065-2077. [CrossRef]

81. Li, J.Y.; McNicholas, K.; Yong, T.Y.; Rao, N.; Coates, P.T.; Higgins, G.D.; Carroll, R.P.; Woodman, R.J.; Michael, M.Z.; Gleadle, J.M. BK virus encoded microRNAs are present in blood of renal transplant recipients with BK viral nephropathy. Am. J. Transpl. Off. J. Am. Soc. Transpl. Am. Soc. Transplant. Surg. 2014, 14, 1183-1190. [CrossRef] [PubMed]

82. Meehan, S.M.; Kadambi, P.V.; Manaligod, J.R.; Williams, J.W.; Josephson, M.A.; Javaid, B. Polyoma virus infection of renal allografts: Relationships of the distribution of viral infection, tubulointerstitial inflammation, and fibrosis suggesting viral interstitial nephritis in untreated disease. Hum. Pathol. 2005, 36, 1256-1264. [CrossRef] [PubMed]

83. Ahuja, M.; Cohen, E.P.; Dayer, A.M.; Kampalath, B.; Chang, C.C.; Bresnahan, B.A.; Hariharan, S. Polyoma virus infection after renal transplantation. Use of immunostaining as a guide to diagnosis. Transplantation 2001, 71, 896-899. [CrossRef] [PubMed]

84. Jahnukainen, T.; Malehorn, D.; Sun, M.; Lyons-Weiler, J.; Bigbee, W.; Gupta, G.; Shapiro, R.; Randhawa, P.S.; Pelikan, R.; Hauskrecht, M.; et al. Proteomic analysis of urine in kidney transplant patients with BK virus nephropathy. J. Am. Soc. Nephrol. JASN 2006, 17, 3248-3256. [CrossRef] [PubMed]

85. Mannon, R.B.; Hoffmann, S.C.; Kampen, R.L.; Cheng, O.C.; Kleiner, D.E.; Ryschkewitsch, C.; Curfman, B.; Major, E.; Hale, D.A.; Kirk, A.D. Molecular evaluation of BK polyomavirus nephropathy. Am. J. Transpl. Off. J. Am. Soc. Transpl. Am. Soc. Transplant. Surg. 2005, 5, 2883-2893. [CrossRef] [PubMed]

86. Sigdel, T.K.; Bestard, O.; Salomonis, N.; Hsieh, S.C.; Torras, J.; Naesens, M.; Tran, T.Q.; Roedder, S.; Sarwal, M.M. Intragraft Antiviral-Specific Gene Expression as a Distinctive Transcriptional Signature for Studies in Polyomavirus-Associated Nephropathy. Transplantation 2016, 100, 2062-2070. [CrossRef] [PubMed]

87. Nickeleit, V.; Singh, H.K.; Randhawa, P.; Drachenberg, C.B.; Bhatnagar, R.; Bracamonte, E.; Chang, A.; Chon, W.J.; Dadhania, D.; Davis, V.G.; et al. The Banff Working Group Classification of Definitive Polyomavirus Nephropathy: Morphologic Definitions and Clinical Correlations. J. Am. Soc. Nephrol. JASN 2018, 29, 680-693. [CrossRef] [PubMed]

88. Li, P.; Cheng, D.; Wen, J.; Ni, X.; Li, X.; Xie, K.; Chen, J. The immunophenotyping of different stages of BK virus allograft nephropathy. Ren. Fail. 2019, 41, 855-861. [CrossRef]

89. Binggeli, S.; Egli, A.; Schaub, S.; Binet, I.; Mayr, M.; Steiger, J.; Hirsch, H.H. Polyomavirus BK-specific cellular immune response to VP1 and large T-antigen in kidney transplant recipients. Am. J. Transpl. Off. J. Am. Soc. Transpl. Am. Soc. Transplant. Surg. 2007, 7, 1131-1139. [CrossRef]

90. Comoli, P.; Hirsch, H.H.; Ginevri, F. Cellular immune responses to BK virus. Curr. Opin. Organ Transpl. 2008, 13, 569-574. [CrossRef]

91. Schmidt, T.; Adam, C.; Hirsch, H.H.; Janssen, M.W.; Wolf, M.; Dirks, J.; Kardas, P.; Ahlenstiel-Grunow, T.; Pape, L.; Rohrer, T.; et al. BK polyomavirus-specific cellular immune responses are age-dependent and strongly correlate with phases of virus replication. Am. J. Transpl. Off. J. Am. Soc. Transpl. Am. Soc. Transplant. Surg. 2014, 14, 1334-1345. [CrossRef] [PubMed]

92. Masutani, K.; Shapiro, R.; Basu, A.; Tan, H.; Wijkstrom, M.; Randhawa, P. The Banff 2009 Working Proposal for polyomavirus nephropathy: A critical evaluation of its utility as a determinant of clinical outcome. Am. J. Transplant. Off. J. Am. Soc. Transplant. Am. Soc. Transpl. Surg. 2012, 12, 907-918. [CrossRef] [PubMed]

93. Schachtner, T.; Muller, K.; Stein, M.; Diezemann, C.; Sefrin, A.; Babel, N.; Reinke, P. BK virus-specific immunity kinetics: A predictor of recovery from polyomavirus BK-associated nephropathy. Am. J. Transpl. Off. J. Am. Soc. Transplant. Am. Soc. Transplant. Surg. 2011, 11, 2443-2452. [CrossRef] [PubMed]

94. Menter, T.; Mayr, M.; Schaub, S.; Mihatsch, M.J.; Hirsch, H.H.; Hopfer, H. Pathology of resolving polyomavirus-associated nephropathy. Am. J. Transplant. Off. J. Am. Soc. Transplant. Am. Soc. Transplant. Surg. 2013, 13, 1474-1483. [CrossRef]

95. Masutani, K.; Tsuchimoto, A.; Matsukuma, Y.; Kurihara, K.; Nishiki, T.; Kitada, H.; Tanaka, M.; Kitazono, T.; Tsuruya, K. Temporal serum creatinine increase and exacerbation of tubulointerstitial inflammation during the first two months in resolving polyomavirus BK nephropathy. Nephrology 2015, 20, 45-50. [CrossRef]

96. Prosser, S.E.; Orentas, R.J.; Jurgens, L.; Cohen, E.P.; Hariharan, S. Recovery of BK virus large T-antigen-specific cellular immune response correlates with resolution of BK virus nephritis. Transplantation 2008, 85, 185-192. [CrossRef]

97. Trydzenskaya, H.; Sattler, A.; Muller, K.; Schachtner, T.; Dang-Heine, C.; Friedrich, P.; Nickel, P.; Hoerstrup, J.; Schindler, R.; Thiel, A.; et al. Novel approach for improved assessment of phenotypic and functional characteristics of BKV-specific T-cell immunity. Transplantation 2011, 92, 1269-1277. [CrossRef]

98. Stervbo, U.; Nienen, M.; Weist, B.J.D.; Kuchenbecker, L.; Hecht, J.; Wehler, P.; Westhoff, T.H.; Reinke, P.; Babel, N. BKV Clearance Time Correlates With Exhaustion State and T-Cell Receptor Repertoire Shape of BKV-Specific T-Cells in Renal Transplant Patients. Front. Immunol. 2019, 10, 767. [CrossRef]

99. Bischof, N.; Hirsch, H.H.; Wehmeier, C.; Amico, P.; Dickenmann, M.; Hirt-Minkowski, P.; Steiger, J.; Menter, T.; Helmut, H.; Schaub, S. Reducing calcineurin inhibitor first for treating BK polyomavirus replication after kidney transplantation: Long-term outcomes. Nephrol. Dial. Transplant. Off. Publ. Eur. Dial. Transplant. Assoc. Eur. Ren. Assoc. 2019, 34, 1240-1250. [CrossRef]

100. Hardinger, K.L.; Koch, M.J.; Bohl, D.J.; Storch, G.A.; Brennan, D.C. BK-virus and the impact of pre-emptive immunosuppression reduction: 5-year results. Am. J. Transplant. Off. J. Am. Soc. Transplant. Am. Soc. Transplant. Surg. 2010, 10, 407-415. [CrossRef]

101. Yamazaki, T.; Shirai, H.; Tojimbara, T. Use of Leflunomide as an Antiviral Agent with Everolimus for BK Virus Nephropathy Patients After Kidney Transplantation: A Case Series. Am. J. Case Rep. 2020, 21, e927367. [PubMed] 
102. Funahashi, Y.; Hattori, R.; Kinukawa, T.; Kimura, H.; Nishiyama, Y.; Gotoh, M. Conversion from mycophenolate mofetil to mizoribine for patients with positive polyomavirus type BK in urine. Transplant. Proc. 2008, 40, 2268-2270. [CrossRef] [PubMed]

103. Yuan, X.; Chen, C.; Zheng, Y.; Wang, C. Conversion From Mycophenolates to Mizoribine Is Associated With Lower BK Virus Load in Kidney Transplant Recipients: A Prospective Study. Transplant. Proc. 2018, 50, 3356-3360. [CrossRef] [PubMed]

104. Belliere, J.; Kamar, N.; Mengelle, C.; Allal, A.; Sallusto, F.; Doumerc, N.; Game, X.; Congy-Jolivet, N.; Esposito, L.; Debiol, B.; et al. Pilot conversion trial from mycophenolic acid to everolimus in ABO-incompatible kidney-transplant recipients with BK viruria and/or viremia. Transplant. Int. Off. J. Eur. Soc. Organ. Transplant. 2016, 29, 315-322. [CrossRef]

105. Hwang, S.D.; Lee, J.H.; Lee, S.W.; Kim, J.K.; Kim, M.J.; Song, J.H. High-Dose Intravenous Immunoglobulin Treatment of Polyomavirus Nephropathy Developing After T Cell-Mediated Rejection Treatment: A Case Report. Transplant. Proc. 2018, 50, 2575-2578. [CrossRef]

106. Piburn, K.H.; Al-Akash, S. Use of intravenous immunoglobulin in a highly sensitized pediatric renal transplant recipient with severe BK DNAemia and rising DSA. Pediatr. Transplant. 2020, 24, e13600. [CrossRef]

107. Kuten, S.A.; Patel, S.J.; Knight, R.J.; Gaber, L.W.; DeVos, J.M.; Gaber, A.O. Observations on the use of cidofovir for BK virus infection in renal transplantation. Transplant. Infect. Dis. Off. J. Transplant. Soc. 2014, 16, 975-983. [CrossRef]

108. Wu, S.W.; Chang, H.R.; Lian, J.D. The effect of low-dose cidofovir on the long-term outcome of polyomavirus-associated nephropathy in renal transplant recipients. Nephrol. Dial. Transplant. Off. Publ. Eur. Dial. Transplant. Assoc. Eur. Ren. Assoc. 2009, 24, 1034-1038. [CrossRef]

109. Gabardi, S.; Waikar, S.S.; Martin, S.; Roberts, K.; Chen, J.; Borgi, L.; Sheashaa, H.; Dyer, C.; Malek, S.K.; Tullius, S.G.; et al. Evaluation of fluoroquinolones for the prevention of BK viremia after renal transplantation. Clin. J. Am. Soc. Nephrol. CJASN 2010, 5, 1298-1304. [CrossRef]

110. Levy, J.B.; Pusey, C.D. Nephrotoxicity of intravenous immunoglobulin. QJM Mon. J. Assoc. Phys. 2000, 93, 751-755. [CrossRef]

111. Walker, R.C. The fluoroquinolones. Mayo Clin. Proc. 1999, 74, 1030-1037. [CrossRef]

112. Roufosse, C.; Simmonds, N.; Clahsen-van Groningen, M.; Haas, M.; Henriksen, K.J.; Horsfield, C.; Loupy, A.; Mengel, M.; Perkowska-Ptasinska, A.; Rabant, M.; et al. A 2018 Reference Guide to the Banff Classification of Renal Allograft Pathology. Transplantation 2018, 102, 1795-1814. [CrossRef] [PubMed]

113. Haas, M.; Loupy, A.; Lefaucheur, C.; Roufosse, C.; Glotz, D.; Seron, D.; Nankivell, B.J.; Halloran, P.F.; Colvin, R.B.; Akalin, E.; et al. The Banff 2017 Kidney Meeting Report: Revised diagnostic criteria for chronic active T cell-mediated rejection, antibody-mediated rejection, and prospects for integrative endpoints for next-generation clinical trials. Am. J. Transpl. Off. J. Am. Soc. Transplant. Am. Soc. Transplant. Surg. 2018, 18, 293-307. [CrossRef] [PubMed]

114. Sood, P.; Senanayake, S.; Sujeet, K.; Medipalli, R.; Zhu, Y.R.; Johnson, C.P.; Hariharan, S. Management and outcome of BK viremia in renal transplant recipients: A prospective single-center study. Transplantation 2012, 94, 814-821. [CrossRef] [PubMed]

115. Parajuli, S.; Astor, B.C.; Kaufman, D.; Muth, B.; Mohamed, M.; Garg, N.; Djamali, A.; Mandelbrot, D.A. Which is more nephrotoxic for kidney transplants: BK nephropathy or rejection? Clin. Transplant. 2018, 32, e13216. [CrossRef] [PubMed]

116. Cheungpasitporn, W.; Kremers, W.K.; Lorenz, E.; Amer, H.; Cosio, F.G.; Stegall, M.D.; Gandhi, M.J.; Schinstock, C.A. De novo donor-specific antibody following BK nephropathy: The incidence and association with antibody-mediated rejection. Clin. Transplant. 2018, 32, e13194. [CrossRef] [PubMed]

117. Kayler, L.K.; Batal, I.; Mohanka, R.; Morgan, C.; Basu, A.; Shapiro, R.; Randhawa, P.S. Antirejection treatment in kidney transplant patients with BK viruria. Transplantation 2008, 86, 797-803. [CrossRef]

118. Alquadan, K.F.; Santos, A.H.; Leghrouz, M.; Ozrazgat-Baslanti, T.; Bozorgmehri, S.; Gupta, G.; Womer, K.L. A pilot study of immunosuppression resumption following BK viremia resolution. Transplant. Infect. Dis. Off. J. Transplant. Soc. 2020, 13508, e13508. [CrossRef]

119. Dharnidharka, V.R.; Cherikh, W.S.; Neff, R.; Cheng, Y.; Abbott, K.C. Retransplantation after BK virus nephropathy in prior kidney transplant: An OPTN database analysis. Am. J. Transplant. Off. J. Am. Soc. Transplant. Am. Soc. Transplant. Surg. 2010, 10, 1312-1315. [CrossRef]

120. Leeaphorn, N.; Thongprayoon, C.; Chon, W.J.; Cummings, L.S.; Mao, M.A.; Cheungpasitporn, W. Outcomes of kidney retransplantation after graft loss as a result of BK virus nephropathy in the era of newer immunosuppressant agents. Am. J. Transplant. Off. J. Am. Soc. Transplant. Am. Soc. Transplant. Surg. 2020, 20, 1334-1340. [CrossRef]

121. Geetha, D.; Sozio, S.M.; Ghanta, M.; Josephson, M.; Shapiro, R.; Dadhania, D.; Hariharan, S. Results of repeat renal transplantation after graft loss from BK virus nephropathy. Transplantation 2011, 92, 781-786. [CrossRef] [PubMed]

122. Hirsch, H.H.; Ramos, E. Retransplantation after polyomavirus-associated nephropathy: Just do it? Am. J. Transplant. Off. J. Am. Soc. Transplant. Am. Soc. Transplant. Surg. 2006, 6, 7-9. [CrossRef] [PubMed]

123. Funk, G.A.; Steiger, J.; Hirsch, H.H. Rapid dynamics of polyomavirus type BK in renal transplant recipients. J.Infect. Dis. 2006, 193, 80-87. [CrossRef] [PubMed] 